\title{
Implementasi DFPlayer untuk Al-Qur'an Digital berbasis Mikrokontroler ESP32
}

\author{
Rizki Priya Pratama ${ }^{1 *}$, Abdullah Mas'ud ${ }^{2}$, Choirun Niswatin ${ }^{1}$, Arif Ainur Rafiq ${ }^{3}$ \\ ${ }^{1}$ Politeknik Kota Malang \\ ${ }^{2}$ Politeknik Negeri Malang \\ ${ }^{1}$ Politeknik Negeri Cilacap \\ *e-mail : rizkipriyap@gmail.com
}

\begin{abstract}
Abstrak-Modul DFPlayer biasa digunakan untuk aplikasi suara, seperti alarm, bel sekolah atau aplikasi yang tidak membutuhkan pengelolahan file mp3 yang banyak. Namun dengan metode yang tepat, DFPlayer juga dapat mengelola file mp3 Al-Quran yang berjumlah 6236 buah dengan baik. Artikel ini akan menunjukkan salah satu metode untuk membaca file mp3 Al-Qur'an sehingga seluruh ayat-ayat Al-Qur'an dapat dilantunkan. Metode tersebut adalah menyusun dan mengurutkan nama file mp3 pada folder MP3, membuat algoritma konversi nama urutan file mp3 dan algoritma pemutaran mp3 berdasarkan rentang ayat secara berurutan. Perangkat ini dirancang dengan memanfaatkan mikrokontroler ESP32 sebagai unit pengontrol utama, modul DFPlayer sebagai dekoder audio dan aplikasi Android sebagai pemilih surah dan ayat yang akan diputar. Hasil pengujian yang didapatkan bahwa pemutaran surah pada juz 30 dan pemutaran rentang ayat pada seluruh surah berhasil $100 \%$.
\end{abstract}

\section{Kata Kunci : DFPlayer, ESP32, Al-Qur'an, MP3}

\begin{abstract}
DFPlayer modules are commonly used for voice applications, such as alarms, school bells or applications that do not require much $\mathrm{mp3}$ file management. But with the right method, DFPlayer can also manage Al-Quran mp3 files totaling 6236 pieces properly. This article will show one method for reading Al-Qur'an's mp3 files so that all the verses of the Qur'an can be recited. The methods such as arranging and sorting mp3 file names, making mp3 file name conversion algorithms and $\mathrm{mp3}$ playback algorithms based on verse ranges in sequence. This device is designed by utilizing the ESP32 microcontroller as the main controller unit, the DFPlayer module as an audio decoder and the Android application as the surah selector and the verse to be played. The test results found that the playback of the surah in juz 30 and the playback of the range of verses in all the suras were $100 \%$ successful.
\end{abstract}

Keywords : DFPlayer, ESP32, Al-Qur'an, MP3

This is an open access article distributed under the Creative Commons 4.0 Attribution License

\section{Pendahuluan}

Perkembangan teknologi digital memiliki peran dalam membantu setiap muslim agar dapat mempelajari atau mendengarkan cara melafalkan Al-Qur'an dengan baik dan benar[1]. Pada penelitian sebelumnya yang berhubungan modul suara atau $\mathrm{mp} 3$, perangkat yang dirancang masih memiliki keterbatasan, antara lain belum dapat melantunkan sejumlah ayat-ayat tertentu secara berurutan dan juga masih ditemukannya ayat yang tidak sesuai dengan pilihan dikarenakan keterbatasan pada komponen penyimpan lantunan ayat-ayat AlQur'an[2] serta adanya metode pembacaan file mp3 Al-Qur'an yang kurang tepat[3].

Penelitian ini bertujuan untuk menunjukkan salah metode untuk membaca file mp3 Al-Qur'an sehingga seluruh ayat-ayat Al-Qur'an dapat diakses dan dilantunkan dengan menggunakan modul DFPlayer. Menurut lembar data, DFPlayer ini hanya dapat mengenali folder hingga 99 folder yaitu folder 01-99 dan pada setiap folder dapat 
mengenali hingga 255 file mp3[4]. Sedangkan, jumlah surah dalam Al-Qur'an berjumlah 114 surah, sehingga folder sisanya sejumlah 14 surah tidak dapat dikenali. Kemudian berdasarkan jumlah file dalam setiap folder dibatasi 255 file mp3, sedangkan jumlah ayat terbanyak dari AlQur'an sebanyak 286 sehingga ada beberapa ayat sisanya tidak dapat dikenali.

Meskipun demikian, selain folder-folder yang bernama urutan angka 01-99, DFPlayer ini mempunyai folder bernama MP3 dan ADVERT. Folder MP3 pada DFPlayer dapat membaca file hingga 9999 file mp3. Sedangkan, jumlah total ayat dalam Al-Qur'an berjumlah 6236, sehingga berdasarkan data tersebut, peneliti dapat memasukkan semua file ayat Al-Qur'an ke dalam folder MP3.

Untuk memutar file mp3 Al-Quran, terdapat 2 pilihan yaitu pilihan 1 untuk folder MP3, dapat memainkan seluruh ayat pada Al-Qur'an 30 juz dengan qari Syaikh Abdurrahman Sudais. Pilihan ke 2, surah yang dimainkan hanya juz 30 dengan qari Muhammad Thaha Al-Junayd. Pengaturan pemutaran file mp3 ini dilakukan dengan HP Android yang telah terinstall Aplikasi.

\section{Metode}

Metode yang telah dilakukan pada penelitian ini adalah metode eksperimental. Perancangan dilakukan mulai dari perancangan perangkat keras hingga perancangan perangkat lunak.

\section{A. Perancangan Perangkat Keras}

Diagram blok perangkat keras secara keseluruhan ditunjukkan pada Gambar 1. Diagram blok ini terdiri dari rangkaian modul audio DFPlayer mini yang selanjutnya disebut DFPlayer, Mikrokontroler ESP32 dan Handphone (HP) Android sebagai pemberi perintah.

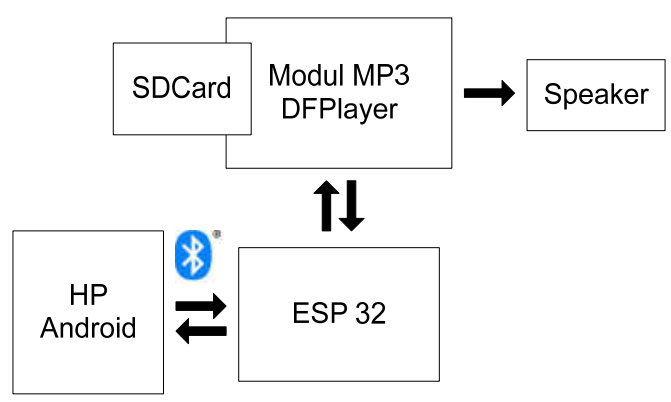

Gambar 1. Diagram blok pemutar mp3 Al-Qur'an

Mikrokontroler ESP32 berfungsi sebagai unit pengontrol komponen yang digunakan pada perangkat. ESP32 ini bertugas untuk menterjemahkan perintah dari HP Android melalui komunikasi bluetooth dan kemudian ESP32 mengendalikan dan memberikan perintah pada modul DFPlayer.

ESP32 ini dilengkapi dengan fitur berupa Bluetooth dan WiFi[5], namun yang digunakan untuk aplikasi ini berupa Bluetooth SPP (Serial Port Profile) yang nantinya terhubung dengan HP Android. Gambar 2 merupakan gambar mikrokontroler ESP32.

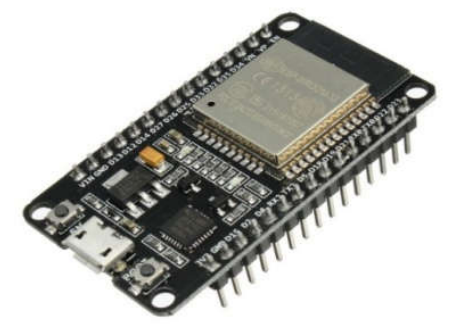

\section{Gambar 2. ESP32[5]}

Modul DFPlayer digunakan sebagai dekoder audio untuk mengubah file audio digital ke dalam suara. File audio yang digunakan adalah file dengan ekstensi .mp3 yang dimasukkan pada SD Card dengan File System FAT32. DFPlayer ini dapat bekerja sendiri secara standalone ataupun bekerja bersama dengan mikrokontroler melalui koneksi serial[4]. Gambar modul DFPlayer dapat dilihat pada Gambar 3.

Pada mode standalone, semua file mp3 pada SD Card dapat dikenali dan dapat diputar meskipun tidak sesuai format penulisan seperti aturan datasheet. Namun supaya dapat dikendalikan oleh mikrokontroler ESP32, maka penulisannya harus sesuai format seperti pada Tabel 1.

Tabel 1. Format penulisan nama file DFPlayer

\begin{tabular}{|c|l|c|}
\hline No & Nama Folder & \multicolumn{1}{c|}{ Nama file } \\
\hline 1 & $01-99$ & $001 . \mathrm{mp} 3-255 . \mathrm{mp} 3$ \\
\hline 2 & MP3 & $0001 . \mathrm{mp} 3-9999 . \mathrm{mp} 3$ \\
\hline 3 & ADVERT & $0001 . \mathrm{mp} 3-9999 . \mathrm{mp} 3$ \\
\hline
\end{tabular}

Module DFPlayer sudah memiliki amplifier namun daya power amplifier yang dihasilkan kecil sehingga cukup untuk digunakan pada speaker kecil $4-8$ Ohm. Selain itu, DFPlayer ini mempunyai pin DAC stereo (kiri dan kanan) untuk masukan amplifier luar. 


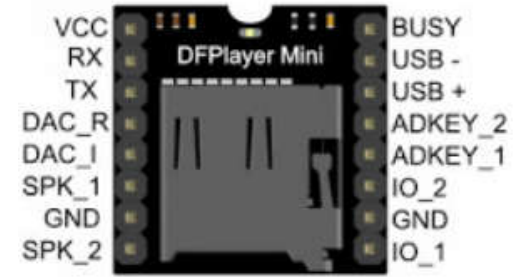

Gambar 3. Modul DFPlayer Mini[4]

Gambar 4 merupakan gambar skematik dari rangkaian player Al-Quran digital. Mikrokontroler ESP32 mengendalikan modul DFPlayer melalui komunikasi serial pada pin TX1 dan RX1 dengan boudrate 9600, dan masuk ke DFPlayer melalui pin TX dan RX.

Mikrokontroler ESP32 membutuhkan catu sebesar 3.3 volt, yang didapatkan dari internal regulator AMS1117-3.3 pada development board ESP32. Sedangkan catu untuk development board ini sebesar 5 volt yang didapatkan dari pin Vin, atau port USB. Untuk keluaran audio, speaker dihubungkan dengan pin SPK_1 dan SPK_2.

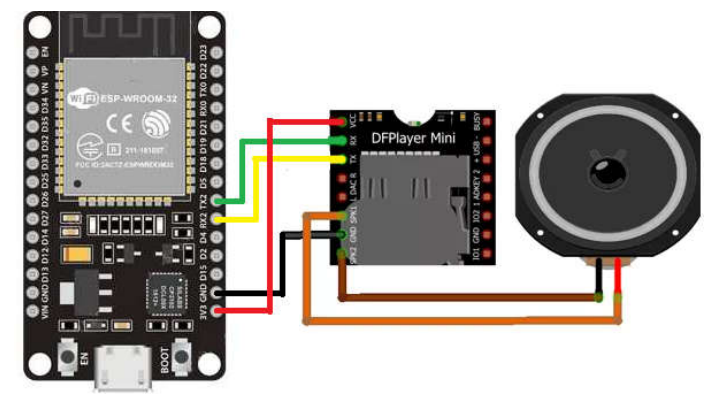

Gambar 4. Skematik rangkaian Pemutar mp3 Al-Quran.

\section{B. Perancangan Perangkat Lunak}

Perancangan perangkat lunak dilakukan untuk mengatur jalannya program pada mikrokontroler agar dapat mengolah data yang diterima melalui bluetooth dan untuk mengendalikan DFPlayer. Mikrokontroler ESP32 diprogram dengan tools PlatformIO pada software Visual Studio Code dengan library yang dibutuhkan seperti DFRobotDFPlayerMini dan BluetoothSerial.

Library DFRobotDFPlayerMini mempunyai beberapa fungsi yang digunakan pada penelitian ini antara lain playMp3Folder, playFolder, stop, next, read, dan volume. Kegunaan dari masingmasing fungsi tersebut dapat dilihat pada Tabel 2. Sedangkan library BluetoothSerial berguna untuk melayani proses komunikasi bluetooth mulai dari inisialisasi identitas nama bluetooth hingga proses penerimaan dan pengambilan data.
Tabel 2. Kegunaan fungsi pada library DFRobotDFPlayerMini

\begin{tabular}{|l|l|l|}
\hline No & Functions & Kegunaan \\
\hline 1 & playMp3Folder(int $)$ & $\begin{array}{l}\text { memutar file mp3 } \\
\text { dari 1 - 9999 pada } \\
\text { folder MP3 }\end{array}$ \\
\hline 2 & playFolder(int, int) & $\begin{array}{l}\text { memutar file mp3 } \\
\text { dari 1 - 255 pada } \\
\text { folder 01 hingga } \\
\text { folder 99 }\end{array}$ \\
\hline 3 & stop() & $\begin{array}{l}\text { menghentikan } \\
\text { pemutaran file mp3 }\end{array}$ \\
\hline 4 & next() & $\begin{array}{l}\text { melanjutkan } \\
\text { pemutaran file mp3 } \\
\text { berikutnya }\end{array}$ \\
\hline 5 & read() & $\begin{array}{l}\text { membaca nilai dari } \\
\text { file yang sedang } \\
\text { diputar. }\end{array}$ \\
\hline 6 & volume(int $)$ & $\begin{array}{l}\text { membesarkan dan } \\
\text { mengecilkan volume } \\
\text { pemutaran file mp3 }\end{array}$ \\
\hline
\end{tabular}

Perintah untuk memutar file $\mathrm{mp} 3$ ayat $\mathrm{Al}$ Qur'an berasal dari HP Android yang telah terinstall aplikasi sederhana buatan peneliti. Gambar 5 merupakan aplikasi untuk mengendalikan perangkat Al-Qur'an digital ini.

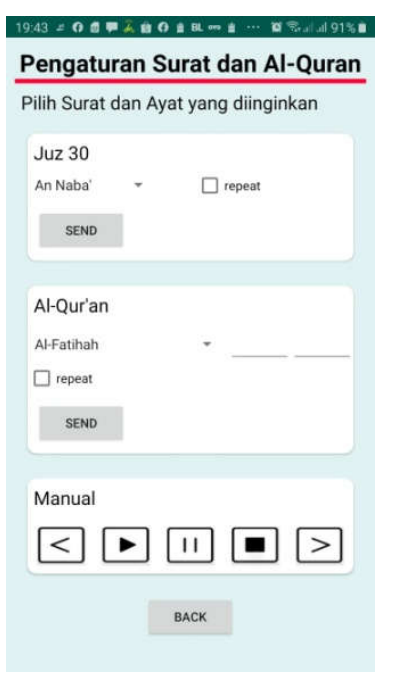

a

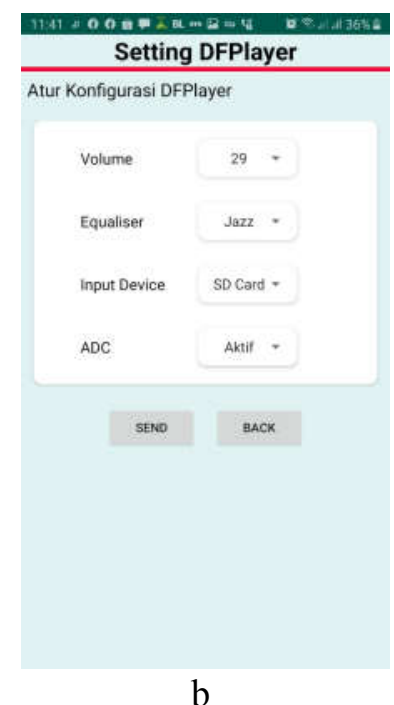

b
Gambar 5. Aplikasi untuk mengendalikan perangkat Al-Qur'an digital.

Aplikasi ini juga berguna untuk membantu proses pengujian pembacaan surah pada Juz 30 hingga pembacaan Al-Qur'an dari Surah AlFatihah hingga surah An-Nas. Gambar 5.a merupakan form untuk memutar surah pada Juz 
30 dan surah pada Al-Qur'an seluruhnya. Gambar 5.b adalah form untuk mengatur volume, equalizer, input device, dan ADC output enable.

Saat tombol send ditekan pada aplikasi, maka HP Android akan mengirimkan perintah sesuai dengan format seperti pada Gambar 6 . play_mode $=\mathrm{xx}: 0: 0: 0: 0$

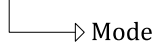

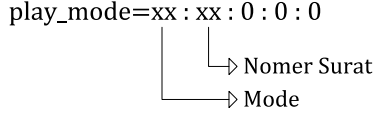

b play_mode $=\mathrm{xx}: \mathrm{xxx}: \mathrm{xxx}: \mathrm{xxx}: \mathrm{x}$

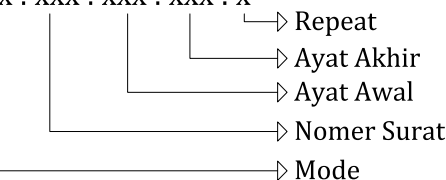

c

Gambar 6. Format perintah Bluetooth dari HP Android

Format perintah bluetooth Gambar 6 adalah sama, tergantung pada nilai mode yang diberikan. Format perintah pada Gambar 6.a ini digunakan untuk mode bernilai 1, 2, 3, 4, 5, 6, 7, 10, 11, 12 dan 13 yaitu perintah untuk play, stop, pause, stop, reset dan lain-lain Keterangan mode ini dapat ditunjukkan pada Tabel 3. Untuk modemode ini, parameter Nomer Surah, Ayat Awal, Ayat Akhir dan Repeat bernilai nol.

Format perintah pada Gambar 6.b digunakan untuk mode bernilai 9, untuk memutar file juz 30 . Pada mode ini, parameter Ayat Awal dan Ayat Akhir tidak digunakan. Sedangkan format perintah pada Gambar 6.c merupakan format perintah dengan mode bernilai 8. Mode ini digunakan untuk memutar seluruh ayat di semua juz atau pada Al-Qur'an.

Tabel 3. Mode perintah DFPlayer

\begin{tabular}{|c|c|l|}
\hline NO & $\begin{array}{c}\text { Nilai } \\
\text { Mode }\end{array}$ & \multicolumn{1}{|c|}{ Keterangan } \\
\hline 1 & 1 & Previous \\
\hline 2 & 2 & Start \\
\hline 3 & 3 & Pause \\
\hline 4 & 4 & Next \\
\hline 5 & 5 & volumeUp \\
\hline 6 & 6 & volumeDown \\
\hline 7 & 7 & Stop \\
\hline 8 & 8 & Play per ayat (30 Juz) \\
\hline 9 & 9 & $\begin{array}{l}\text { Play satu surah (Juz } \\
30)\end{array}$ \\
\hline 10 & 10 & Reset \\
\hline 11 & 11 & Pengaturan Volume \\
\hline 12 & 12 & Setting Equaliser \\
\hline 13 & 13 & Output Device \\
\hline
\end{tabular}

Data perintah dari HP Android tadi ditampung dulu pada variable data_bluetooth pada ESP32, yang kemudian di proses sehingga dapat dikenali nilai parameter Mode, Nomer Surah, Ayat Awal, Ayat Akhir dan Repeat. Syntax untuk menerjemahkan perintah dari HP Android pada ESP32 adalah sebagai berikut :

if (sscanf(data_bluetooth,

"play_mode $=\% \mathrm{~d}: \% \mathrm{~d}: \% \mathrm{~d}: \% \mathrm{~d}: \% \mathrm{~d} ", \&$ mode, \&no_surah, \&ayat_awal, \&ayat_akhir, \&playRepeat)==5)

Tabel 4. Urutan nama file MP3 Al-Quran

\begin{tabular}{|c|c|c|c|c|}
\hline \multirow{2}{*}{$\begin{array}{c}\text { No } \\
\text { Surah }\end{array}$} & \multirow{2}{*}{ Surah } & \multirow{2}{*}{$\begin{array}{c}\text { Jumlah } \\
\text { ayat }\end{array}$} & \multicolumn{2}{|c|}{ Nama urutan file mp3 } \\
\hline & & & Awal & Akhir \\
\hline 1 & Surah Al-Fatihah & 7 & 0001 & 0007 \\
\hline 2 & Surah Al-Baqarah & 286 & 0008 & 0293 \\
\hline 3 & Surah Ali 'Imran & 200 & 0294 & 0493 \\
\hline 4 & Surah An-Nisa' & 176 & 0494 & 0669 \\
\hline 5 & Surah Al-Ma'idah & 120 & 0670 & 0789 \\
\hline 6 & Surah Al-An'am & 165 & 0790 & 0954 \\
\hline 7 & Surah Al-A'raf & 206 & 0955 & 1160 \\
\hline 8 & Surah Al-Anfal & 75 & 1161 & 1235 \\
\hline 9 & Surah At-Taubah & 129 & 1236 & 1364 \\
\hline 10 & Surah Yunus & 109 & 1365 & 1473 \\
\hline 11 & Surah Hud & 123 & 1474 & 1596 \\
\hline 12 & Surah Yusuf & 111 & 1597 & 1707 \\
\hline 13 & Surah Ar-Ra'd & 43 & 1708 & 1750 \\
\hline 14 & Surah Ibrahim & 52 & 1751 & 1802 \\
\hline 15 & Surah Al-Hijr & 99 & 1803 & 1901 \\
\hline 16 & Surah An-Nahl & 128 & 1902 & 2029 \\
\hline 17 & Surah Al-Isra' & 111 & 2030 & 2140 \\
\hline 18 & Surah Al-Kahf & 110 & 2141 & 2250 \\
\hline 19 & Surah Maryam & 98 & 2251 & 2348 \\
\hline 20 & Surah Ta Ha & 135 & 2349 & 2483 \\
\hline 95 & Surah At-Tin & 8 & 6099 & 6106 \\
\hline 96 & Surah Al-'Alaq & 19 & 6107 & 6125 \\
\hline 97 & Surah Al-Qadr & 5 & 6126 & 6130 \\
\hline 98 & Surah Al-Bayyinah & 8 & 6131 & 6138 \\
\hline 99 & Surah Az-Zalzalah & 8 & 6139 & 6146 \\
\hline 100 & Surah Al-'Adiyat & 11 & 6147 & 6157 \\
\hline 101 & Surah Al-Qari'ah & 11 & 6158 & 6168 \\
\hline 102 & Surah At-Takasur & 8 & 6169 & 6176 \\
\hline 103 & Surah Al-'Asr & 3 & 6177 & 6179 \\
\hline 104 & Surah Al-Humazah & 9 & 6180 & 6188 \\
\hline 105 & Surah Al-Fil & 5 & 6189 & 6193 \\
\hline 106 & Surah Quraisy & 4 & 6194 & 6197 \\
\hline 107 & Surah Al-Ma'un & 7 & 6198 & 6204 \\
\hline 108 & Surah Al-Kausar & 3 & 6205 & 6207 \\
\hline 109 & Surah Al-Kafirun & 6 & 6208 & 6213 \\
\hline 110 & Surah An-Nasr & 3 & 6214 & 6216 \\
\hline 111 & Surah Al-Lahab & 5 & 6217 & 6221 \\
\hline 112 & Surah Al-Ikhlas & 4 & 6222 & 6225 \\
\hline 113 & Surah Al-Falaq & 5 & 6226 & 6230 \\
\hline 114 & Surah An-Nas & 6 & 6231 & 6236 \\
\hline
\end{tabular}


Beberapa pengaturan harus dilakukan agar DFPlayer dapat memutar file mp3 sesuai dengan surah dan ayat yang diinginkan. Pengaturan tersebut antara lain menyusun nama file mp3 ke dalam format yang sesuai, menentukan dan membuat algoritma program.

Penulisan nama file $\mathrm{mp} 3$ ini harus sesuai dengan aturan pada datasheet, karena jika tidak sesuai maka file mp3 ini tidak akan dikenali oleh DFPlayer. Penulisan nama file pada folder MP3 mempunyai kombinasi 4 digit. Contohnya adalah penulisan nama file 1.mp3 menjadi 0001.mp3. Sedangkan pada folder 01 hingga folder 99 penulisan mempunyai kombinasi 3 digit yaitu 001.mp3 hingga 255.mp3.

Folder-folder pada SD Card DFPlayer yang digunakan untuk pembacaaan Al-Qur'an adalah folder MP3 dan sebuah folder 01. Pada folder MP3 seluruh nama file diurutkan mulai angka 0001.mp3 hingga angka 6236.mp3, berdasarkan ayat pertama di surah Al-Fatihah hingga ayat terakhir di surah An-Nas, seperti pada Tabel 4.

Untuk mengubah nama / rename file, kami menggunakan aplikasi windows yaitu powershell dengan intruksi sebagai berikut :

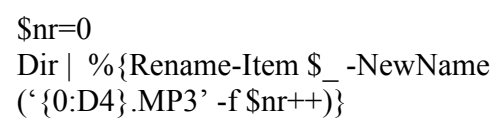

Setelah nama file mp3 Al-Qur'an terletak di dalam folder MP3, langkah selanjutnya adalah membuat algoritma dan program untuk membaca file-file tersebut. Masukan yang diberikan pada mikrokontroler ESP32 berupa nomer surah dan ayat dan keluarnya menjadi nama urutan file mp3. Proses tersebut ditunjukkan pada Gambar 7.

Proses untuk menentukan nama urutan file mp3 dari nomer surah 3 dan ayat 4 adalah sebagai berikut: dengan perulangan, variabel no_ayat mp3 akan berjumlah $7+286$, angka 7 merupakan jumlah ayat dari surah Al-Fatihah, dan angka 286 adalah jumlah surah Al-Baqarah. Proses tersebut membutuhkan sebuah array yang menampung jumlah ayat yang berada pada setiap surah. Selanjutnya karena ayat yang diminta adalah 4 maka jumlahnya adalah $(7+286)+4=297$, sehingga nama urutan file mp3-nya adalah 0297.mp3. Berikut flowchat untuk menjelaskan proses diatas dapat dilihat pada Gambar 8 .

Setelah menentukan nama urutan file $\mathrm{mp} 3$ dari masukan nomer surah dan nomer ayat maka proses selanjutnya adalah melakukan pembacaan rentang ayat secara berurutan, sebagai contoh An-
Nisa 4 - 9. Pemutaran file mp3 surah An-Nisa dengan nomer surah 4 dari ayat ke 4 hingga ke 9 .

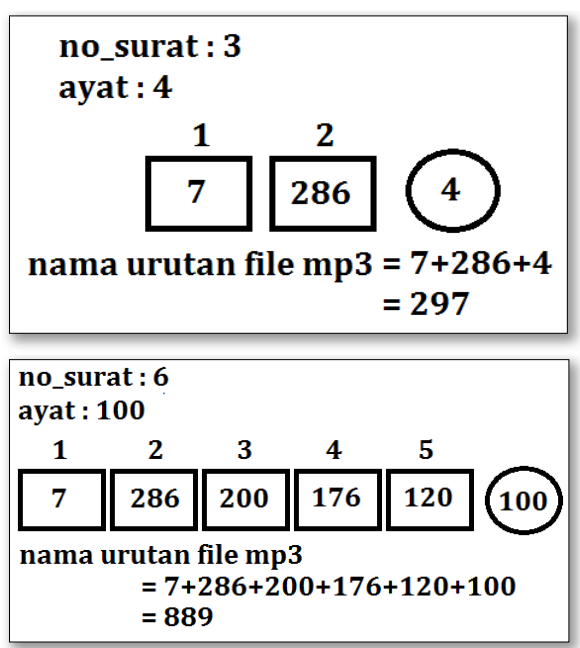

Gambar 7. Proses konversi dari nomer surah dan ayat menjadi nama urutan file $\mathrm{mp} 3$.

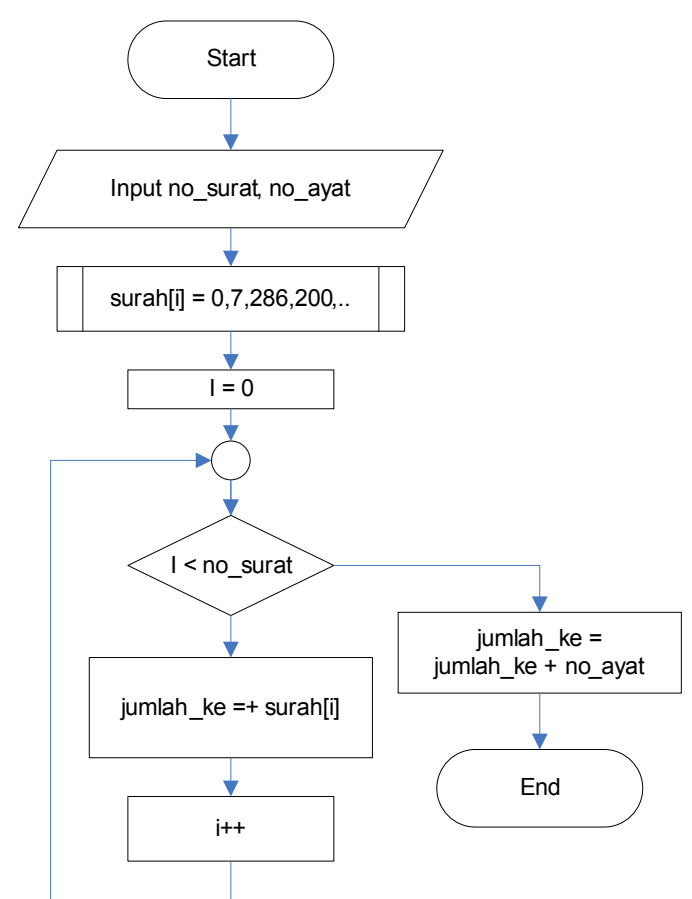

Gambar 8. Flowchart konversi dari nomer surah dan ayat menjadi nama urutan file mp3.

Proses ini terdapat 3 masukan yaitu nomer surah, nomer ayat awal dan nomer ayat akhir. Nomer surah dan nomer ayat awal akan dikonversi menjadi nama urutan file mp3 sebelumnya. Setelah nama urutan file mp3 diputar, ESP32 akan membaca nomer file DFPlayer tersebut. Nomer file hasil pembacaan DFPlayer berbeda dengan nama file mp3.

Kemudian nomer file hasil pembacaan DFPlayer dijumlahkan dengan selisih antara 
nomer ayat awal dan nomer ayat akhir menjadi nomer ayat_target. Jika nomer ayat_target sama dengan nomer ayat pembacaan DFPlayer saat ini, maka pemutaran berhenti, jika belum maka DFPlayer memutar urutan file selanjutnya. Proses tersebut dapat dilihat pada flowchart Gambar 9.

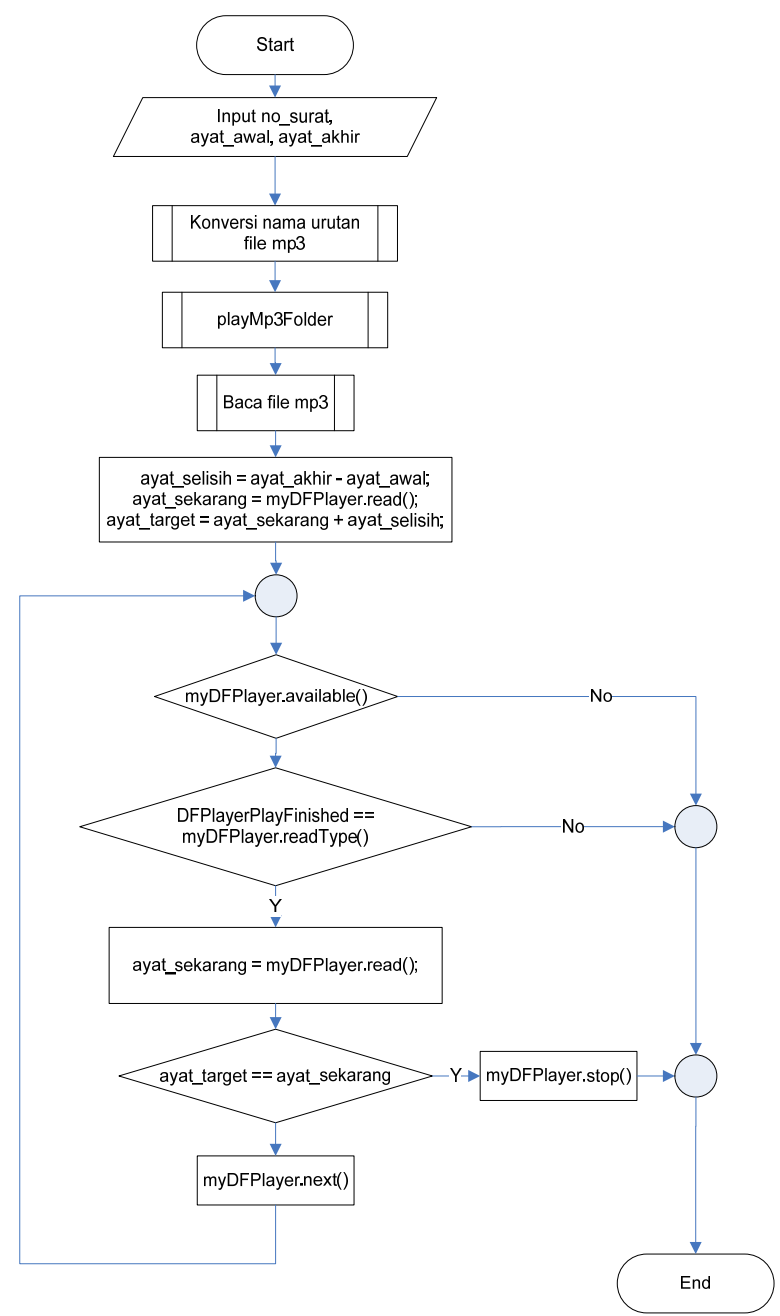

Gambar 9. Flowchart pemutaran mp3 rentang ayat secara berurutan

\section{HASIL DAN PEMBAHASAN}

Pengujian dilakukan untuk mengetahui apakah alat atau sistem berfungsi dengan benar atau tidak. Pada penelitian ini dilakukan 2 pengujian, yaitu pengujian surah pada juz 30 dan pengujian rentan ayat tertentu pada surah.

\section{A. Pengujian surah pada juz 30.}

Pada pengujian surah pada juz 30, sistem harus dapat melantunkan ayat-ayat dari surah yang dipilih secara lengkap. Aplikasi pada HP Android digunakan untuk memilih surah yang akan diputar seperti ditunjukkan pada Gambar 10. Gambar 10 ini menunjukan bahwa surah yang dipilih adalah surah Al-Lahab. Setelah tombol send ditekan, aplikasi PC serial monitor yang dihubungkan pada port USB ESP32 akan mengeluarkan pesan play_mode $=9: 34: 0: 0: 0$ seperti yang dapat dilihat pada Gambar 11. Dan seketika speaker akan melantunkan surah AlLahab. Proses pengujian ini dilakukan sebanyak 20 kali dengan nama surah yang berbeda-beda. Hasil pengujian pada Tabel 5. menunjukkan bahwa sistem dapat melantunkan setiap surah yang dipilih dengan benar.

\begin{tabular}{l} 
Pengaturan Surat dan Al-Quran \\
\hline Pilih Surat dan Ayat yang diinginkan \\
JUZ 30 \\
Al-Lahab $\quad \square$ repeat \\
SEND
\end{tabular}

Gambar 10. Aplikasi pemutaran surah pada juz 30

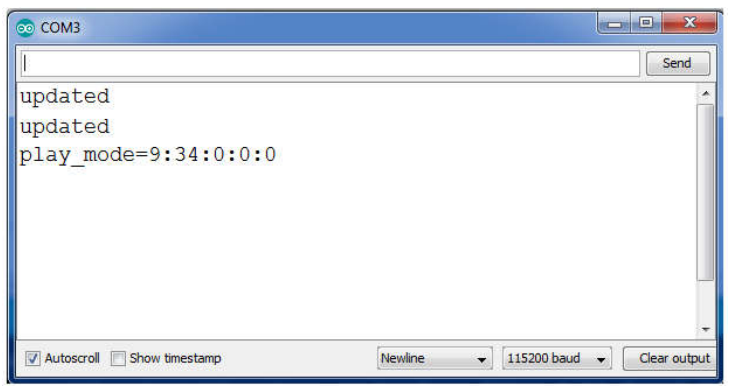

Gambar 11. Serial monitor

Tabel 5. Hasil pengujian surah pada juz 30

\begin{tabular}{|l|l|l|l|l|}
\hline NO & Perintah Bluetooth & Surah & $\begin{array}{l}\text { Ter- } \\
\text { lantun }\end{array}$ & $\begin{array}{l}\text { Se- } \\
\text { suai }\end{array}$ \\
\hline 1 & play_mode=9:1:0:0:0 & AnNaba & Ya & Ya \\
\hline 2 & play_mode=9:37:0:0:0 & Annas & Ya & Ya \\
\hline 3 & play_mode=9:31:0:0:0 & Al Kausar & Ya & Ya \\
\hline 4 & play_mode=9:3:0:0:0 & 'Abasa & Ya & Ya \\
\hline 5 & play_mode=9:36:0:0:0 & Al-Falaq & Ya & Ya \\
\hline 6 & play_mode=9:28:0:0:0 & Al-Fill & Ya & Ya \\
\hline 7 & play_mode=9:32:0:0:0 & Al-Kafirun & Ya & Ya \\
\hline 8 & play_mode=9:30:0:0:0 & Al-Ma'un & Ya & Ya \\
\hline 9 & play_mode=9:26:0:0:0 & Al-'Asr & Ya & Ya \\
\hline 10 & play_mode=9:22:0:0:0 & $\begin{array}{l}\text { Az- } \\
\text { Zalzalah }\end{array}$ & Ya & Ya \\
\hline 11 & play_mode=9:7:0:0:0 & $\begin{array}{l}\text { Al- } \\
\text { Insyiqaq }\end{array}$ & Ya & Ya \\
\hline 12 & play_mode=9:10:0:0:0 & Al-A'la & Ya & Ya \\
\hline 13 & play_mode=9:13:0:0:0 & Al-Balad & Ya & Ya \\
\hline 14 & play_mode=9:18:0:0:0 & At-Tin & Ya & Ya \\
\hline 15 & play_mode=9:29:0:0:0 & Quraisy & Ya & Ya \\
\hline 16 & play_mode=9:24:0:0:0 & Al-Qari'ah & Ya & Ya \\
\hline 17 & play_mode=9:33:0:0:0 & An-Nasr & Ya & Ya \\
\hline 18 & play_mode=9:25:0:0:0 & At-Takasur & Ya & Ya \\
\hline 19 & play_mode=9:27:0:0:0 & $\begin{array}{l}\text { Al- } \\
\text { Humazah }\end{array}$ & Ya & Ya \\
\hline 20 & play_mode=9:20:0:0:0 & Al-Qadr & Ya & Ya \\
\hline
\end{tabular}




\section{B. Pengujian rentan ayat pada surah}

Proses pengujian surah seluruh juz pada AlQur'an hampir sama dengan proses pengujian surah pada juz 30. Aplikasi untuk memilih surah yang akan diputar dapat dilihat pada Gambar 12. Gambar 12 menunjukkan bahwa surah yang dipilih adalah surah Al-Baqarah 2 - 5 .

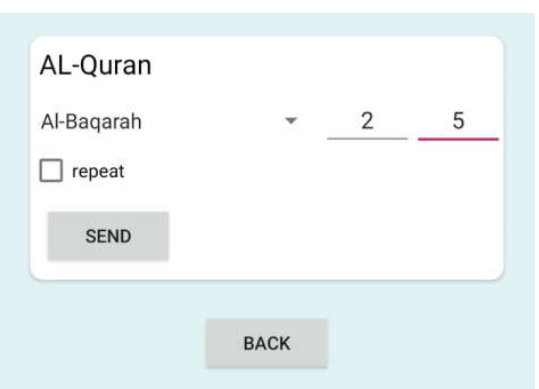

Gambar 12. Aplikasi pemutaran rentan ayat pada surah

Setelah tombol send ditekan, serial monitor menampilkan pesan play_mode $=8: 2: 2: 5: 0$, hal ini ditunjukkan pada Gambar 13. Angka delapan merupakan mode untuk dapat memutar seluruh ayat pada 30 juz, angka dua berarti surah AlBaqarah sedangkan angka dua dan lima adalah ayat awal dan ayat akhir. Penjelasan tersebut dapat dilihat pada Gambar 14.

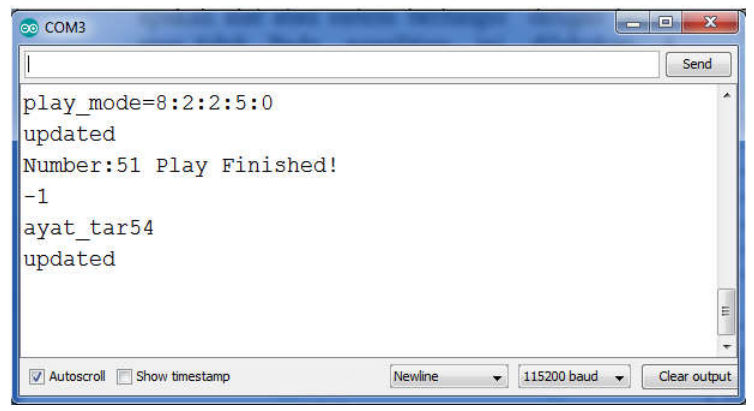

Gambar 13. Serial monitor

play_mode $=8: 2: 2: 5: 0$

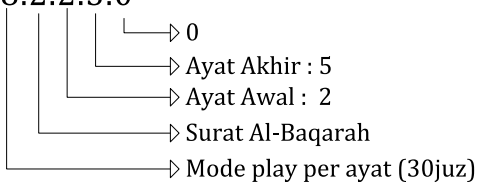

Gambar 14. Format perintah Bluetooth yang sudah diterima ESP32

Proses ini dilakukan sebanyak 25 kali dengan nama surah dan ayat yang berbeda-beda. Hasil pengujian pada Tabel 6. menunjukkan bahwa sistem dapat melantunkan setiap surah yang dipilih dengan benar.
Tabel 6. Hasil pengujian rentan ayat tertentu pada surah

\begin{tabular}{|l|l|l|l|}
\hline NO & Perintah Bluetooth & Surah & $\begin{array}{l}\text { Terl- } \\
\text { antun }\end{array}$ \\
\hline 1 & play_mode=8:2:2:5:0 & Al-Baqarah 2-5 & Ya \\
\hline 2 & play_mode=8:34:1:22:0 & Saba' 1-22 & Ya \\
\hline 3 & play_mode=8:20:15:20:0 & Ta Ha 15-20 & Ya \\
\hline 4 & play_mode=8:14:1:7:0 & Ibrahim 1-7 & Ya \\
\hline 5 & play_mode=8:16:1:7:0 & An-Nahl 1-7 & Ya \\
\hline 6 & play_mode=8:18:10:17:0 & Al-Kahf 10-17 & Ya \\
\hline 7 & play_mode=8:19:1:12:0 & Maryam 1-12 & Ya \\
\hline 8 & play_mode=8:2:255:286:0 & $\begin{array}{l}\text { Al-Baqarah 255- } \\
\text { 286 }\end{array}$ & Ya \\
\hline 9 & play_mode=8:3:100:120:0 & $\begin{array}{l}\text { Ali 'Imran 100- } \\
\text { 120 }\end{array}$ & Ya \\
\hline 10 & play_mode=8:4:2:12:0 & An-Nisa' 2-12 & Ya \\
\hline 11 & play_mode=8:7:10:20:0 & Al-A'raf 10-20 & Ya \\
\hline 12 & play_mode=8:8:12:30:0 & Al-Anfal 12-30 & Ya \\
\hline 13 & play_mode=8:38:1:25:0 & Sad 1-25 & Ya \\
\hline 14 & play_mode=8:10:15:30:0 & Yunus 15:30 & Ya \\
\hline 15 & play_mode=8:11:19:30:0 & Hud 19-30 & Ya \\
\hline 16 & play_mode=8:25:3:40:0 & Al-Furqan 3-40 & Ya \\
\hline 17 & play_mode=8:27:1:15:0 & An-Naml 1-15 & Ya \\
\hline 18 & play_mode=8:110:1:2:0 & An-Nasr 1-2 & Ya \\
\hline 19 & play_mode=8:112:1:4:0 & Al-Ikhlas 1-4 & Ya \\
\hline 21 & play_mode=8:114:1:5:0 & An-Nas 1-5 & Ya \\
\hline 22 & play_mode=8:36:1:15:0 & Ya Sin 1-83 & Ya \\
\hline 23 & play_mode=8:90:4:15:0 & Al-Balad 4-15 & Ya \\
\hline 24 & play_mode=8:39:10:25:0 & Az-Zumar 10-25 & Ya \\
\hline 25 & play_mode=8:40:1:35:0 & Ghafir 1-35 & Ya \\
\hline
\end{tabular}

\section{KESIMPULAN}

Berdasarkan hasil penelitian dan percobaan yang telah dilakukan, diperoleh beberapa kesimpulan sebagai berikut

Sistem dapat berfungsi dengan baik, DFPlayer dapat bekerja dengan baik sebagai dekoder audio dan data pada SD Card dapat dikenali oleh mikrokontroler ESP32.

Pengiriman data melalui bluetooth dari HP Android ke mikrokontroler ESP32 tidak mengalami kendala dan langsung diterjemahkan menjadi mode, surah, ayat awal dan ayat akhir yang ditandai dengan adanya lantunan Al-Qur'an yang sesuai dengan surah dan ayat yang dipilih.

Metode penyusunan urutan nama file mp3 AlQur'an dan metode pembacaan file mp3 AlQur'an pada modul DFPlayer berjalan dengan baik.

Hasil Pengujian surah pada juz 30 dan Pengujian rentan ayat tertentu pada surah berhasil $100 \%$

Adapun saran untuk pengembangan berikutnya adalah penambahan pilihan beberapa qari dan mengaplikasikan metode ini pada perangkat display jadwal sholat, perangkat pembelajaran anak usia dini atau perangkat AlQur'an braille. 


\section{DAfTAR PUSTAKa}

[1] Y. Masduki. (2018) .Implikasi Psikologis Bagi Penghafal Al-Qur'an. J. Medina-Te, vol. 18 , no. $1, .18-35$.

[2] H. Hidayat, F. Rahmatullah. (2014). Rancang Bangun AL-Qur'an Audio Player by Ayah (QuPA) 1.0. Maj. Ilm. Unikom, vol. 12, no. 1, pp. 53-60.

[3] Hidayat, L Nurjanah (2018). Perancangan alQur'an Player untuk Tunanetra menggunakan Mikrokontroler dan DFPlayer. Jurnal Sistem Komputer. Vol. 7, No. 2, 87 - 94

[4] DFrobot, 2014. DFPlayer Mini Manual, https://wiki.dfrobot.com/DFPlayer_Mini_SK U_DFR0299

[5] Espressif Systems. (2018). ESP32 Series Datasheet, https://www.espressif.com.

\section{Biodata Penulis}

Rizki Priya Pratama, menempuh kuliah S1 di Teknik Elektro Universitas Brawijaya dan S2 DDIP di Universitas Indonesia jurusan Kontrol Industri, dan Universite' D'Anger, Perancis. Penulis dilahirkan di Pasuruan, 23 Juni 1981 dan merupakan dosen Teknik Mekatronika Politeknik Kota Malang.
Abdullah Mas'ud, menempuh pendidikan S1 Pendidikan Fisika, FKIE , IKIP Malang dan S2 Teknik Mesin Universitas Brawijaya Malang, Penulis dilahirkan di Ternate, 28 Maret 1956 dan merupakan dosen dosen Jurusan Teknik Elektro, Politeknik Negeri Malang.

Choirun Niswatin dilahirkan di Lamongan Jawa Timur, 05 Juni 1973 dan menjadi dosen Tetap di Politeknik Kota Malang sejak 2008. Telah menempuh kuliah S1 di Pendidikan Bahasa Inggris Universitas Muhammadiyah Malang dan menyelesaikan program Master Applied Linguistics di Northumbria University at Newcastle, UK.

Arif Ainur Rafiq, Staf pengajar di Jurusan Teknik Elektronika, Politeknik Negeri Cilacap. Menyelesaikan Sarjana di Universitas Islam Indonesia, Yogyakarta tahun 2005. Program Magister dari Universitas Indonesia dan Universite de Bretagne Occidentale, Brest Prancis melalui Program Double Degree Indonesia Perancis, selesai tahnu 2011. Bidang riset yang ditekuni adalah instrumentasi, sensor transduser, devais elektronika, IoT dan embedded system. 